NBER WORKING PAPER SERIES

\title{
PREFERENCES, INFORMATION, AND PARENTAL CHOICE BEHAVIOR IN PUBLIC SCHOOL CHOICE
}

\author{
Justine S. Hastings \\ Richard Van Weelden \\ Jeffrey Weinstein \\ Working Paper 12995 \\ http://www.nber.org/papers/w12995
}

\author{
NATIONAL BUREAU OF ECONOMIC RESEARCH \\ 1050 Massachusetts Avenue \\ Cambridge, MA 02138 \\ March 2007
}

\begin{abstract}
We would like to thank Charlotte-Mecklenburg Schools for allowing us to study parental choice behavior in its district. Jacob Gramlich and Hillary Gramlich provided excellent assistance creating and distributing the information sheets. We would also like to thank Judy Chevalier, Alan Gerber, Donald Green, Thomas Kane, Dean Karlan, Michael Kremer, Sendhil Mullainathan, Douglas Staiger, Rebecca Thornton, Ebonya Washington, and participants at the Yale University Institution for Social and Policy Studies lunch, the Yale University Labor-Public Finance Lunch, and the 2006 Economic Science Association conference for valuable input. We gratefully acknowledge support from the Smith Richardson Foundation and the Institution for Social and Policy Studies at Yale University. The views expressed herein are those of the author(s) and do not necessarily reflect the views of the National Bureau of Economic Research.

(C) 2007 by Justine S. Hastings, Richard Van Weelden, and Jeffrey Weinstein. All rights reserved. Short sections of text, not to exceed two paragraphs, may be quoted without explicit permission provided that full credit, including (C) notice, is given to the source.
\end{abstract}


Preferences, Information, and Parental Choice Behavior in Public School Choice

Justine S. Hastings, Richard Van Weelden, and Jeffrey Weinstein

NBER Working Paper No. 12995

March 2007

JEL No. D8,I2,L3

\begin{abstract}
$\underline{\text { ABSTRACT }}$
The incentives and outcomes generated by public school choice depend to a large degree on parents' choice behavior. There is growing empirical evidence that low-income parents place lower weights on academics when choosing schools, but there is little evidence as to why. We use a field experiment in the Charlotte-Mecklenburg Public School district (CMS) to examine the degree to which information costs impact parental choices and their revealed preferences for academic achievement. We provided simplified information sheets on school average test scores or test scores coupled with estimated odds of admission to students in randomly selected schools along with their CMS school choice forms. We find that receiving simplified information leads to a significant increase in the average test score of the school chosen. This increase is equivalent to a doubling in the implicit preference for academic performance in a random utility model of school choice. Receiving information on odds of admission further increases the effect of simplified test score information on preferences for test scores among low-income families, but dampens the effect among higher-income families. Using within-family changes in choice behavior, we provide evidence that the estimated impact of simplified information is more consistent with lowered information costs than with suggestion or saliency.
\end{abstract}

Justine S. Hastings

Yale University

P.O. Box 208264

New Haven, CT 06520-8264

and NBER

justine.hastings@yale.edu

Richard Van Weelden

Yale University

P.O. Box 208268

New Haven, CT 06520-8268

richard.vanweelden@yale.edu
Jeffrey Weinstein

Yale University

P.O. Box 208268

New Haven, CT 06520-8268

jeffrey.weinstein@yale.edu 


\section{Introduction}

School choice plans are intended to improve both education quality and equity by providing incentives for schools to compete on academic achievement and by allowing broader access to quality public schools. Several urban public school districts are currently experimenting with public school choice plans, and the federal No Child Left Behind Act (NCLB) includes a choice provision allowing students in failing schools to choose to attend non-failing schools outside of their neighborhood. The goal is to allow disadvantaged students to benefit academically from attending higher-performing schools and to increase pressure on failing schools to improve through the threat of losing students.

However, the incentives and outcomes generated by school choice depend to a large degree on parents' choice behavior. There is growing empirical evidence that parental preferences are very heterogeneous and that low-income parents place lower values on academic characteristics when choosing schools (Fossey (1994), Armor and Peiser (1998), Schneider and Buckley (2002), Hastings, Kane, and Staiger (2006a), Jacob and Lefgren (2007)). Using multiple-ranked choice data from the introduction of school choice in the Charlotte-Mecklenburg Public School district (CMS), Hastings, Kane, and Staiger (2006a, b) find that low-income families place lower implicit weights on academics when choosing schools. They show that these lower preferences for academics have a negative impact on both marginal student outcomes and the pressure for school quality improvement in CMS.

It may be the case that, all else equal, low-income families place lower weights on school test scores because they rationally expect lower returns to education for their children. Alternatively, low-income families may face higher information or decision-making costs. They may place a high value on academic outcomes but find it more costly to act on those preferences, leading to a lower revealed preference for school test scores. Recent empirical research has shown that lowincome households may have higher decision-making costs when faced with complex decisions, such as picking the best school or investing in financial assets (Caskey (1994), Bertrand et al. (2006), Duflo et al. (2006), McFadden (2006), Winter et al. (2006)). Our paper uses a field experiment to examine the degree to which information costs impact parental choices and their 
revealed preferences for academic achievement. For the 2006-2007 school choice process, CMS allowed us to provide simplified information sheets with parents' school choice application forms. These sheets were sent out with the CMS choice forms in the spring of 2006 to students in randomly selected schools that serve primarily low- to middle-income neighborhoods. The sheets provided either clear statistics on academic achievement of schools in the child's choice set or information on academic achievement coupled with estimated odds of admission. The simplified information was given to students at both Title I Improving schools (NCLB schools), where since 2004 parents have received some sort of information as part of the No Child Left Behind Act, and students at non-NCLB schools where parents do not receive statistics on academic outcomes for their school choices.

Using administrative data on student characteristics and parental choice responses, we show, among students in the non-NCLB panel, that receiving test score information led to a significant increase in the test score of the first-choice school relative to the test score at their guaranteed school. However, simplified information had no significant impact on choice behavior for those in the NCLB panel. We also find, using a conditional logit model, that receiving simplified information on test scores doubled estimated parental preferences for test scores in the nonNCLB sample of students. This effect is large in magnitude and does not seem to vary with income. However, the effect of receiving information on odds of admission with test scores increased preferences for test scores more among lower-income households than among higherincome households relative to receiving information on test scores alone. This suggests that lower-income households responded to odds information by choosing higher-performing schools, while higher-income households responded by choosing slightly lower-performing schools with better odds of admission. Using our conditional logit estimates, we find, for the non-NCLB sample, that the probability of choosing a non-guaranteed school would have increased by 8 percentage points (off of a base of 31\%) had all families received simplified information on test scores. Thus a small intervention appears to have had a large impact on demand.

We identify siblings of students in the treatment and control groups to examine if the effect of simplified information is potentially driven by suggestion and saliency or reduced information 
costs. For example, when a family receives simplified information on the school options for the elementary school child, test scores are made more salient for children's education and parents may interpret the form as suggesting that they should value test scores. However, the costs of finding that information have only been decreased for the elementary school child and not for siblings at different education levels (middle or high school in this example). We do not find a significant impact on choices for such siblings of treated students, lending support to the hypothesis that lowered information costs and not increased saliency are driving the main effects.

This paper is organized as follows. Section 2 reviews the relevant literature on both parental preferences in school choice and the effects of information costs on decision making. Section 3 explains the CMS school choice plan, and Section 4 describes the design of the field experiment. Section 5 discusses the empirical results, and Section 6 concludes.

\section{Literature Review}

\subsection{Parental Preferences and School Choice}

Because preferences are central to understanding the implications of public school choice, there has been a strong interest in understanding parents' choice behavior. Survey responses generally show that parents list academic achievement and teacher quality among the most important school characteristics (Armor and Peiser (1998), Greene et al. (1998), Schneider et al. (1998), Vanourek et al. (1998), Kleitz et al. (2000)). In particular, parents in lower socio-economic groups state that they value academics as much as other parents do, ranking academic factors as the most important reasons for exercising school choice. However, parents’ stated preferences may be altered to fit social norms - emphasizing a high value for education quality, a low value for convenience, and potentially downplaying concerns for school racial composition. Furthermore, when responding to hypothetical questions, parents may make assumptions that affect their responses in ways not apparent to the researcher (e.g. automatically incorporating the importance of proximity in their responses). 
Another body of research has used observed choice behavior to learn about the factors that drive parental choice. Most of the evidence indicates that underlying preferences for school characteristics are very heterogeneous and that parents with lower socio-economic status appear to place a significantly lower value on academic school characteristics. Schneider and Buckley (2002) monitored the search behavior of parents on an Internet web site for public schools in Washington, DC and found that academics and student body compositions are more important search criteria for students of college-educated parents than they are for students of parents without a college education. Fossey (1994) and Armor and Peiser (1998) studied the characteristics of school districts' gaining and losing students in a Massachusetts interdistrict choice program. They find evidence that non-minority students and those with higher test scores were more likely to change districts. Jacob and Lefgren (2007) use data on parents' choices for teachers within schools to examine what parents seem to value in the classroom. They find that while families in higher poverty schools strongly value student achievement when choosing teachers, within schools low-income and minority parents are less likely than their more advantaged peers to actively request teachers.

More recently, Hastings, Kane, and Staiger (2006a) use data from the introductory year (20022003) of the CMS school choice plan to estimate preferences for school characteristics from parents' multiple-ranked choices for school assignments. They estimate a mixed-logit demand model for schools and find that the preference attached to a school's mean test score increases with student income and baseline academic achievement and that idiosyncratic preferences for test scores are negatively correlated with those for proximity. They conclude that the significant differences in preferences across socio-economic groups may lead to disparate demand-side pressure to improve academic performance under school choice. Hastings, Kane, and Staiger (2006b) use the same school choice data to test if attending a first-choice school results in academic gains. They use randomized assignment of students to first-choice schools to estimate the effect of attending a first-choice school on student achievement, allowing the treatment effect to vary with the implicit weight parents placed on test scores when choosing their schools. They find that students of parents who placed high weights on academics experienced academic gains when randomized into their first-choice school. Students of parents who placed a low weight on academics (typically low-income) experienced academic losses. 


\subsection{Information Costs and Decisions}

There is a recent literature that uses field experiments to examine the causes for sub-optimal behavior in complex decisions such as savings and retirement investments. Madrian and Shea (2001) show that the default options for retirement savings enrollment and investment in an employer's retirement savings plan have substantial effects on the savings behavior of employees. Choi et al. (2006) show that offering a simplified retirement plan option that has predetermined investments and contribution rates and requires a simple affirmative decision to participate has a significant impact on retirement savings participation. They conclude that retirement savings options that significantly reduce the complexity of the decision-making tasks can facilitate participation.

Duflo et al. (2006) focus in particular on retirement savings among low- to middle-income households. They examine the effect of randomized matching incentives to increase IRA participation among low- to middle-income families. They show that simple matching incentives have a significant impact on both IRA participation and IRA contributions, where more complex tax credit incentives had failed. They conclude that simplified information provision and ease of participation can have important impacts on increasing both retirement savings participation and savings rates among low- to middle-income families.

Hastings and Weinstein (2007) use CMS data to examine the effect NCLB notification had on parents' choices and subsequent student outcomes. They use the first year of integration of NCLB into the CMS choice plan at the end of the 2003-2004 school year. They compare the choices parents made in the spring (prior to notification) with the choices they made in that summer after receiving their NCLB notification letter. They find that approximately 16\% of students responded to the letter and chose to attend schools with average test scores approximately 1 standard deviation higher than the schools they chose to attend just a few months earlier. They provide evidence that student who won lotteries to attend significantly better schools experienced academic gains relative to lottery losers. They conclude that NCLB 
notification led to a significant change in choice behavior, and that those changed choices allowed some students to benefit academically as well.

\section{CMS School Choice Plan}

\subsection{History}

Before the introduction of a school choice plan in the fall of 2002, the Charlotte-Mecklenburg Public School district (CMS) operated under a racial desegregation order for three decades. In the 2002-2003 school year, CMS moved to a district-wide school choice plan in response to a court order to cease busing for racial integration. In the spring of 2002, parents were asked to submit their top three choices of school programs for each child. Each student was assigned a "home school" in her neighborhood. This school was typically one of the closest schools to her, and she was guaranteed admission to this school if she was not admitted to any of her top three choices. Admission to non-guaranteed schools was granted based on a lottery.

In the initial implementation of the school choice program, CMS underwent a large redistricting of home school assignments: approximately $50 \%$ of parcels lost property rights to the school they had rights to under busing. In the first year of choice the district required every parent to submit a choice form, and they achieved a 95\% compliance rate. In each year after the initial choice year, only students in rising grades $\left(\mathrm{K}, 6^{\text {th }}, 9^{\text {th }}\right)$, new students to the district, students affected by the opening of new schools, and students who wished to change schools were required to submit choice forms.

Each year a significant fraction of schools in the district is oversubscribed. ${ }^{1}$ The process of admission to oversubscribed schools by lottery has continued since the introduction of school choice in 2002. Under the lottery system, students are first assigned to priority groups by school and grade. The priority groups have varied from year to year but generally give priority to

\footnotetext{
${ }^{1}$ In the first year, approximately $1 / 3$ of the schools were oversubscribed due to CMS's commitment to expand capacities at schools in an effort to give parents one of their top three choices. In subsequent years, 2/3 of the schools have been oversubscribed as capacities were fixed.
} 
higher-poverty and lower-performing students who choose a lower-poverty, higher-performing school. ${ }^{2}$ Within each priority group, admission is determined by randomly assigned lottery number alone.

\subsection{Information Provision}

\subsubsection{Academic Achievement}

In order for parents to determine which schools to choose, CMS provided several resources. First, each family received a choice book. The choice book was approximately 100 pages long. It contained detailed instructions on how to complete the school choice form and how to submit it along with a brief description of the lottery process. ${ }^{3}$ The bulk of the choice book was devoted to written descriptions of each school and program, from pre-school through high school. There are approximately 120 elementary, 40 middle, and 30 high school choice options in the district. The descriptions were written by the schools, describing the positive features each school offered to students. Objective measures of school characteristics such as average test score performance, suspension rates, or racial compositions were not provided.

In addition, CMS provided a Family Application Center that parents could phone or visit in order to ask questions about the school choice process. The staff members at the Family Application Center were to emphasize the positive aspects of each school during their discussions with parents. In particular, staff members were supposed to respond to questions like 'which school is the best school' by advising parents to discuss with their children what their needs were and then to visit the different school options in order to determine which school was the best for their children, since what a 'good' school is depends on each individual child. ${ }^{4}$

CMS also offers an extensive website. On this website, parents can review statistics for each school one-by-one. The school profiles provide statistics such as physical locations, standardized

\footnotetext{
2 The priority group definitions were initially based on free- and reduced-lunch status and the concentration of freeand reduced-lunch recipients at a school. Since the use of lunch recipient status has been criticized lately, CMS moved to use test score performance as a priority instead. Students performing below average on End Of Year exams are given priority for admission to schools performing at or above the district average on standardized exams.

${ }^{3}$ Parents were not told how the lottery was run (e.g. first-choice maximizer) or how the 'priority boosts' were implemented.

${ }^{4}$ Information from interviews and conversations with Family Application Center staff.
} 
test score performances, suspension rates, racial compositions, and attendance rates. However, statistics for schools were reported as averages for the entire school even if different school programs were housed on the same campus (e.g. magnet program and non-magnet program). This aggregation may mask the true achievement rates of the separate school choice options on each campus. In addition, parents would have to view all statistics for each school separately, instead of viewing a statistic for all of their choice options on one simplified page. Hence, obtaining objective information on schools would involve a significant web search and comparison.

\subsubsection{Information on Odds of Admission}

Although the fraction of parents choosing non-guaranteed school options for their children has remained fairly steady across the years, the number of seats available for choice has decreased significantly at many schools. After the first year of choice, when CMS stopped expanding seats at high-demand schools, many schools effectively stopped admitting any students through the choice lottery. Parents expressed frustration at not gaining admission to any of their chosen schools. ${ }^{5}$ In order to help guide parental choices and minimize frustration, CMS added to the choice book a description of schools (again pooled for campuses, not shown for individual programs) as 'Low,' 'Medium,' or 'High’ capacity utilization. The purpose was to categorize “schools according to their ability to provide space for non-guaranteed seats”. 6 Thus, a 'High' rating for capacity utilization would imply a low probability of admission through the choice plan. This page appeared at the back of the 2004-2005 CMS school choice book. The district did not experience a decline in the number of parents choosing over-subscribed schools. In the 20052006 school year, the district moved the capacity utilization page to page 14 in an attempt to make it more salient to parents; however, the district still did not experience a decline in the choice of over-subscribed schools. In the absence of easy information on academic outcomes, parents may have interpreted low odds of admission as signals of high quality, which may have led to an increase in demand at oversubscribed schools.

\footnotetext{
${ }^{5}$ Hastings, Kane, Staiger, and Weinstein (forthcoming) show that white parents who lost the lottery were significantly more likely to vote in school board elections.

${ }^{6}$ CMS 2004-05 Student Assignment Application Guide. (Page 90).
} 


\subsection{Integration of NCLB into the CMS School Choice Plan}

NCLB legislation was introduced in January of 2002. Beginning in the summer of 2004, CMS implemented NCLB in accordance with North Carolina state regulation that in turn was based on federal requirements. Title I schools face sanctions under NCLB if they fail to make Adequate Yearly Progress (AYP) for two years in a row. As defined by CMS, a school is a Title I school (receives federal Title I funds) if 75\% or more of its students qualify for federal lunch subsidies. As defined by North Carolina under NCLB compliance, a school needs to satisfy certain academic targets for 10 subgroups of students in order to make AYP. ${ }^{7}$ If just one target was missed for one subgroup, then the school failed to make AYP. ${ }^{8}$

In each year since 2004, 16-19 schools have been categorized as Title I Improving and entered into regulation under NCLB. The regulation implied that parents needed to be notified of the NCLB status of their school and offered the choice to attend an alternative school. In addition, the district (as part of a federal requirement) was required to supply with this notification information on the academic achievement of the schools that parents could select. ${ }^{9} \mathrm{CMS}$ provided a three page spreadsheet printout with the percent proficient for every school in the district, as well as list of Title I Improving schools, since students exercising choice under NCLB were not allowed to choose to attend another Title I Improving school.

Thus the NCLB legislation provided statistics to parents on the academic achievement at their school and at every other school in the district, notification that their school failed to meet AYP, and notification of their right to choose to attend another non-NCLB school. This information

\footnotetext{
${ }^{7}$ For North Carolina, the subgroups are the entire school, Asian, American Indian, Black, Hispanic, Multi-racial, White, economically disadvantaged, limited English proficiency, and students with disabilities.

${ }^{8}$ Targets include the percentage of students scoring proficient on North Carolina standardized tests for math and reading for each subgroup (with the percentage needed to make AYP gradually increasing over time in order to meet the federal requirement of 100\% proficiency by the end of the 2013-2014 school year; this requirement can also be satisfied for a subgroup if its percent proficient falls within a 95\% confidence interval for the target percent proficient), a minimum participation rate in each of the exams for each subgroup (95\% in each year or averaged over the prior two or three years), and attendance rates for elementary and middle school students or graduation rates for high school students (an increase of 0.1 percentage point from the previous year or anything over 90\%). For information on other means by which subgroups can make AYP, please see the Consolidated State Application Accountability Workbook for North Carolina (2005) which provides federal NCLB guidelines along with North Carolina's implementation of these guidelines.

${ }^{9}$ U.S. Department of Education. Public school choice. www.ed.gov/policy/elsec/guid/schoolchoiceguid.pdf. (Page 18).
} 
was provided along with the choice form only to parents of students slated to attend a NCLB school in the subsequent school year. The information was provided for two years prior to our experiment. Throughout our analysis we will estimate the effect of simplified information for the non-NCLB panel and NCLB panel separately since we may expect to see a different impact across these two groups.

\subsection{The 2006-2007 School Choice Plan}

Because information on capacity utilization rates failed to choke off demand, and in the interest of minimizing parental discontent, the school board voted to decrease the schools offered for choice. For the 2006-2007 school year, only magnet programs and schools with a non-zero probability of enrollment would be offered for choice. On each student's choice form, the only school choice numbers that would appear would be for the available school choices in their quadrant of the district.

In January of 2006, the new choice forms were distributed to students in the district. As in prior choice years, forms were provided to all students slated to attend NCLB schools (to comply with the choice requirements of the law), to rising grade students (going into $\mathrm{K}, 6^{\text {th }}$, or $9^{\text {th }}$ grade in the next school year), and to students whose home-school assignments for the 2006-2007 school year were affected by the opening of a new school. Our simplified information sheet was attached to this choice form. Parents had one month to submit their choices for the 2006-2007 school year.

\section{Experimental Design}

\subsection{Distribution and Design of Information}

Based on discussions with CMS of results from Hastings, Kane, and Staiger (2006a, b) that lowincome families place lower weights on academics when choosing schools and that students of such families often had test score losses as a result of attending their first-choice school, the district was primarily interested in understanding if simplified information might change the 
expressed choices that parents made. They were also interested in understanding if more precise information on odds of admission might affect parental choice behavior.

The district allowed us to design simplified information sheets in order to examine the effect that such information would have on choices. The information experiment was limited to information on average test scores and on odds of admission. Students attending the same school and living in the same choice zone had to receive the same type of information. Hence information was randomized at the school and choice-zone level (school-zone). ${ }^{10}$ The set of schools was restricted to NCLB schools and non-NCLB schools serving low- to middle-income neighborhoods, and we were asked to limit the number of forms provided to non-NCLB students to around three thousand.

We randomly selected school-zones to receive either Score forms (test score information only) or Odds forms (test scores coupled with odds of admission) out of the set of schools serving low- to middle-income families, subject to the constraints discussed above. The randomization was done separately for each of the segments of schools: pre-K (rising kindergarten), $5^{\text {th }}$ graders (rising $6^{\text {th }}$ ), $8^{\text {th }}$ graders (rising $9^{\text {th }}$ ), and NCLB students. There were 6,328 non-NCLB students in 46 school-zones (39 schools) who were part of the field experiment, and 10,134 NCLB students in 31 school-zones (19 schools) who were part of the experiment.

The forms were specialized for each child. They contained a list of schools in the student's choice set, which depended on the student's choice zone and her home school assignment for the 2006-2007 school year. Figures 1 and 2 provide examples of the simplified information forms. The forms list the schools in the choice set along with program-specific school average scores (and odds of admission where applicable). ${ }^{11}$ The scores were calculated from the prior year's

\footnotetext{
${ }^{10}$ The district was split into 4 quadrants called 'choice zones'. In prior years, parents could choose from any school in the district, but their child would only receive free transportation to schools in their choice zone. For the 20062007 school year, CMS significantly redrew the boundaries of the choice zones so that each zone contained a range of possible schools given the new restricted choice set. Hence, it was often the case that students attending a current school lived in different 2006-2007 choice zones, even though they would have been in the same choice zone under the prior choice zone boundary definition.

${ }^{11}$ Two types of each form were given. One with only numeric information on test scores, and one with a graphical apple rating that represented the numeric scores in addition to the numbers themselves. The graphical addition was randomized within school and homeroom, since it technically added no new information. We did not find that
} 
average performance of students in that school and program on standardized tests and then rescaled to correspond to a percentage score that looks like a grade. The odds of admission were calculated based on the prior year's admission rates. Each simplified information form was stapled to the child's choice form that she would receive.

The information sheets incorporate the CMS logo and its graphic themes and were designed to look as if they were made by and came from the school district, and the school district approved the final design. The staff at the Family Application Center reported seeing parents arriving with their simplified information sheet in hand, with notes written on the forms as they made their decisions.

\subsection{Descriptive Statistics}

Table I gives descriptive statistics for students in the district as a whole as well as for students in the non-NCLB sample and the NCLB sample. Students in the non-NCLB sample are about 15 percentage points more likely to be African American and 15 percentage points more likely to receive federal lunch subsidies than the population of students in the district. They also have lower incomes on average. Throughout this paper, income is measured as the median income in the 2000 Census for people of a student's own race living in a student's block group. Students in the non-NCLB sample also have significantly lower standardized test scores on the North Carolina End of Grade exam. Students in the non-NCLB sample have test scores that are on average one third of a standard deviation below the district mean. They are less likely than the district as a whole to have a week or more of unexcused absences; however, they are more likely to have at least one suspension.

The NCLB sample of students is significantly more likely to be African American and receive federal lunch subsidies than the non-NCLB sample. This is not surprising since the requirement for Title I designation for a school in CMS is $75 \%$ or higher lunch recipient rate. In addition, average income and average test scores are substantially lower for the NCLB students relative to

further simplification affected choices, so we pool the choice forms with graphics and without graphics for this analysis. 
the district and to the non-NCLB sample of students. NCLB students also have higher than average unexcused absences and suspension rates.

Despite the fact that the 2006-2007 school choice plan restricted the set of schools from which students could choose, there is significant variation in school characteristics in each student's choice set. Table II gives summary statistics of the choice set information provided to the students. Students had on average 14 schools to choose from, including their home school. There was substantial variation in average test scores for schools in the choice sets. The average range of test scores gives the average (across students) of the difference between the best- and worstscoring school in their choice set. The average range is 1.325 student level standard deviations for students in the non-NCLB group and 1.275 student level standard deviations for students in the NCLB group. The range of average test scores in the district is a little more than 2. In addition, there is a large range in the odds of admission. Row three shows the minimum chance of admission for schools in the choice set. The average of the minimum admission chances is 0.25 and 0.29 for the non-NCLB and NCLB students, respectively (the maximum chance of admission is 1 for each student's guaranteed choice). Hence, if information costs are a factor influencing parents' choices, there is enough variation in school characteristics that we may expect to see significant changes in choices if simplified information lowers information costs.

\section{Results}

\subsection{Aggregated Reduced-Form Results}

Tables III and IV examine the effect that simplified information had on aggregate choice behavior. Outcome measures of interest are aggregated or averaged at the school-zone level - the level at which the treatment was assigned. Table III reports regression adjusted differences in average baseline characteristics between school-zone combinations receiving Score forms, Odds forms, and those in the control group. The last two columns give the coefficient from an OLS regression of the dependent variable in each row on whether the school-zone received Score or Odds forms, controlling for randomization-block fixed-effects: 
$\bar{y}_{S}=\alpha+\delta R_{S}+\theta T_{S}^{1}+\phi T_{S}^{2}+\varepsilon_{S}$

where $R_{S}$ are randomization-block fixed effects, and $\mathrm{T}_{\mathrm{S}}{ }^{1}$ and $\mathrm{T}_{\mathrm{S}}{ }^{2}$ are indicators if students in school-zone $S$ received the Score form or the Odds form, respectively. Standard errors are reported in parentheses, and p-values are in brackets below each coefficient estimate. All of the coefficients are insignificant implying that baseline characteristics are balanced across schoolzones that received simplified information and those that did not.

Table IV presents regression-adjusted mean differences in aggregated choice behavior between treatment and control groups for three measures of parental choice behavior: the fraction of parents listing a non-guaranteed school as their first choice, the average number of choices parents listed on their child's choice form, and the average difference between the test score of the first-choice school and the test score at the guaranteed school. The dependent variable means are reported in the final rows of each panel in Table IV. Column 1 provides regression results for the pooled sample of school-zones, Column 2 provides results for non-NCLB school-zones, and Column 3 provides results for the NCLB school-zones. Columns 4 through 6 report weighted least squares estimates for the corresponding dependent variable, where the weights are given by the number of students in each school-zone. Standard errors are reported in parentheses, and pvalues are in brackets below each coefficient estimate.

Columns 1 and 4 show that there is no significant of simplified information for any of the three outcome measures in the pooled sample of students. However, the results are very different for the non-NCLB sample and the NCLB sample. For the non-NCLB sample, receiving simplified information on test scores had a (marginally) significant impact on the fraction of parents who listed a non-guaranteed choice as their first choice, increasing the proportion by about 7 percentage points off of a base of 31\%. This implies that simplified information on test scores increased demand for non-guaranteed schools by an economically significant 23\%. Receiving simplified information on odds of admission and test scores did not have a significant impact on the fraction of parents choosing non-guaranteed schools, although the point estimates are similar in magnitude to the point estimates on Score Form. Simplified information on test scores also affected the average number of choices that parents listed. School-zones receiving Score forms 
had a significant $24 \%$ increase in the average number of choices listed relative to the control group ( 0.239 increase off a mean of 1.014 in Column 2 and a 0.241 increase off a mean of 0.966 in Column 5). However, school-zones receiving Odds forms - both odds of admission and test scores - had no significant average increase in the number of choices listed relative to the control group. This implies that knowing the odds of admission along with the test score of each choice decreased the number of choices listed relative to receiving information on test scores alone. This result is slightly counterintuitive. Since the guaranteed choice is guaranteed, one could always list second and third choices without affecting the probability of getting the guaranteed choice. Listing second or third choices should be a (weakly) optimal strategy even if the odds of admission are low. However, it appears that parents responded to information on odds of admission by listing fewer choices than when they received information on test scores alone. Parents may prefer schools that are higher scoring than their guaranteed school; however, if those schools have low odds of admission, they may choose not to list them at all.

Even if receiving odds information seemed to decrease the number of choices listed relative to receiving test scores alone, both forms have similar effects on the average difference between the test score of the first-choice school and the test score at the guaranteed school. The third panel shows that both Score forms and Odds forms caused an increase in the average difference between the test score of the first-choice school and the test score at the guaranteed school of about 0.10 standard deviations (a $70 \%$ increase relative to the mean of 0.14 ). Hence, in the nonNCLB group, parents respond to information on scores or on scores coupled with odds of admission by choosing schools with significantly higher test scores than their current guaranteed option.

Among the NCLB group, there was no significant impact of either type of simplified information on aggregate choice behavior. There are at least two potential reasons for this result. First, recall that for this group of schools both the treatment and control groups received the district's standard Title I choice information sheet along with notification that their school had failed to make Adequate Yearly Progress for at least 2 years in a row. Hence insignificant results imply that our simplified information had no effect above and beyond the information already provided by the district. This may imply that parents are not sensitive to the number of options listed or 
the format in which they are listed; what is important is that the information comes easily in one place with the choice form used in making the decision. Alternatively, it may be the case that this group of parents is relatively inert. Parents who would have responded to NCLB information and notification may have already responded by choosing out in prior years (Hastings and Weinstein (2007)). Hence the remaining students have parents who are not responsive to information on academic outcomes.

\subsection{Student-Level Reduced Form Results}

Examining choice responses at the student level is important for understanding the magnitude of the impact of simplified information and how it compares to other factors that affect parental choice such as income level, school proximity, and school racial composition. It also allows us to examine how the impact of simplified information varies with student and family characteristics, and to test if the impact on parental choice of lowered information is more consistent with suggestion/saliency or with lowered information costs. Sections 5.2 through 5.4 examine the impact of simplified information on parental choices using student-level data.

Tables V and VI present results from regressions of the form

$y_{i}=X_{i} \beta+\delta R_{i}+\theta T_{i}^{1}+\phi T_{i}^{2}+\varepsilon_{i}$

where $\mathrm{X}_{\mathrm{i}}$ are student characteristics such as race and lunch recipient status, as well as characteristics of the student's choice set that might affect her choices such as the score at her guaranteed school, the average distance to local schools, and the average test scores at local schools. The $R_{i}$ are randomization-block fixed effects. $T_{i}^{1}$ and $T_{i}^{2}$ are indicators if the child received the Score form or the Odds form, respectively. Standard errors are clustered at the school-zone and grade level.

Table V presents results for the non-NCLB sample. Each column reports regression results for a different dependent variable. Clustered standard errors are reported in parentheses with p-values in brackets under each coefficient. The first column indicates that receiving a Score form increases the probability that a parent lists a non-guaranteed choice first. The coefficient is marginally significant (p-value of 0.053 ) and translates into a 18\% increase over a base of 31\%. 
The regression allows for an interaction term between income and receiving a Score form to test if the effect is increasing or decreasing in income. Here income is demeaned by the sample mean of $\$ 40,000$, and divided by 1000 . The coefficient on the interaction is negative but insignificant. Receiving an Odds form also has a significant and positive impact on the probability that a parent chooses a non-guaranteed choice first for their child. The point estimate is larger than the one for the Score form but not significantly different. The interaction with income is also significant and negative, indicating that the effect is larger for families with lower income, and smaller for those with higher income. For a family with income of $\$ 30,000$, the effect of receiving an Odds form is 0.117 (a 38\% increase off a base of 31\%). However, for a family with income of $\$ 50,000$, the effect of receiving an Odds form is 0.057 (a $19 \%$ increase off a base of $31 \%)$.

The other right hand side variables control linearly for student characteristics and characteristics of the student's choice set. Parents of African American students were more likely to list a nonguaranteed choice first, but parents of children receiving federal lunch subsidies were less likely to list a non-guaranteed choice first. If the average test scores of schools within 5 miles increases, the probability of listing a non-guaranteed choice increases as well. If the family lives further from the guaranteed school, they are more likely to list a non-guaranteed choice since the guaranteed choice is not so convenient to the family's home that the preference for proximity would make it a dominant choice. In addition, if the test score at the guaranteed choice is higher, the probability of choosing a non-guaranteed choice is much lower. Taken together, these coefficients highlight the tradeoffs we would expect parents to face when deciding which schools to choose for their children.

Column 2 presents regression results where the dependent variable is the number of choices listed. Here, receiving either a Score or an Odds form increased the number of choices listed by $18 \%$ and $19 \%$, respectively ( 0.172 and 0.188 off a base of 0.966 ), although the coefficient on Odds is only marginally significant with a p-value of 0.062 . The coefficients on the interactions of Score and Odds with income are negative, but both are insignificant. Parents of African American students list on average more choices, while parents with higher-scoring guaranteed choices for their children list significantly fewer choices. 
Column 3 gives regression results where the dependent variable is difference between the test score of the first-choice school and the test score at the guaranteed school. Receiving a Score form increases the test score difference by a significant 0.081 student-level standard deviations (a $60 \%$ increase off a base of 0.136). The interaction with income is insignificant. Receiving an Odds form also increases the test score difference, and the interaction effect with income is negative and significant. It implies that, for a family with average income, receiving odds information increases the test score difference by 0.137 student-level standard deviations. This is not significantly different than the effect of receiving a Score form. However, for a family with income of $\$ 25,000$, receiving an Odds form increases the test score difference by 0.167 standard deviations, which is significantly larger than the effect of receiving a Score form.

Hence again, there appears to be a difference in how low-income families respond to information on admission odds relative to the response of middle-income families when choosing schools. Low-income families are not only more likely to choose a non-guaranteed school when they receive simplified information on odds of admission and test scores, but they also choose higherscoring schools. There are a few reasons why this may be the case. First, low-income parents could have less information from peer groups on which schools are good schools. They could interpret odds as an additional signal of a quality school, because it is a school that many people seem to want. This effect may outweigh the strategic desire to weigh admission odds when selecting a school. Second, it may be that low-income households have different risk preferences than middle-to-upper income families do. ${ }^{12}$ Third, low-income families may have different priors on the odds of admission. In this fifth year of school choice, low-income families may believe that they have very low chances of getting into high-scoring schools, while middle-to-high income families believe that they have relatively better chances (despite the fact that lottery priorities favor low-income families over moderate-to-high-income families). ${ }^{13}$ Any of these

\footnotetext{
${ }^{12}$ For example, Guryan and Kearney (2005) find variation across socio-economic groups in patterns of lottery ticket purchases after a winning ticket is sold, providing evidence that risk preferences differ across income levels.

${ }^{13}$ It is not clear why they would have these different priors since historically low-income and low-achieving students have had better odds of admission, given a school choice, due to the priority boosts. This is born out in past admission rates. However, since admission rates and application rates are not published by race or income, parents would not have this information with which to form expectations. We are currently working on a paper exploring how, if at all, parents learn and form expectations on admission odds over the five years of school choice in CMS.
} 
three explanations could generate the relationship between Odds forms and income borne out in the data.

Table VI presents the same regressions as those in Table V but for the NCLB sample of students. There is no significant effect of simplified information on parental choice behavior, relative to the test score information already provided by the district under the NCLB choice requirement. This may imply that further simplification of information does not impact choices; providing concise and objective information on school academic outcomes at the time of choice decision is all that is needed, and further simplification has no added benefit. However, since parents of students at NCLB schools had received notification and information for two years prior to the current year, prompting many of them to choose significantly better schools (Hastings and Weinstein (2007)), the remaining population in the NCLB schools may be unresponsive to any added information on school academic outcomes. This would be consistent with the insignificant effect of Odds forms on parental choices, since the NCLB information requirement did not include information on odds of admission - only information on school average proficiency levels.

\subsection{Preferences for Test Scores}

The results in Tables $\mathrm{V}$ show a strong response to simplified information in the non-NCLB panel. The reduced-form regressions highlight the importance of choice set characteristics such as proximity to high-test-score schools. However, these characteristics are controlled for in an ad-hoc way (e.g. the average test scores of schools within 5 miles). We can instead estimate the parameters of a random utility model, where parents choose the school that maximizes their utility as a function of school and student characteristics. This approach has the added benefit of allowing us to incorporate information contained in all three choices (not just in the first choice) in a natural way. We do so by simply forming the probability that the parent chose their three top choices (in rank order) as a function of school characteristics and using these probabilities to form the likelihood function. ${ }^{14}$

\footnotetext{
${ }^{14}$ So far we have focused on the effect of simplified information on the test score of the first-choice school. It is not clear how to incorporate information on the second and third choices into the dependent variable in a reduced-form
} 
Table VII presents results from conditional logit (fixed-effects) models of school choice using the non-NCLB panel of students. Column 1 presents results using only first choices, while Column 2 presents results using all three choices. Independent variables include characteristics of the school, such as average test score and racial composition, and their interactions with student characteristics, such as distance, racial composition interacted with student race, and school test score interacted with family income. Because we condition out student-level fixed effects, any attribute that varies just at the student level cannot be identified. We allow the preference for school average test score to vary by the type of simplified information the student received.

Results in Column 1 indicate that parents value proximity and their guaranteed home school. In addition, parents value school average test scores, and the value they place on test scores is increasing in income (again income is demeaned and divided by 1000). These coefficients are similar in magnitude to the mean preferences estimated in Hastings, Kane, and Staiger (2006a). In addition, African American students place a positive weight on the fraction African American at a school, while white students place a negative weight; an increase in the fraction African American by 0.5 lowers a white parent's utility for a school by $0.5 * 1.153$ but increases an African American parent's utility for a school by $0.5 *(2.228-1.153) .{ }^{15}$

More importantly, simplified information has a large impact on preferences for school test scores. Estimates in Column 1 indicate that the mean preference for test scores approximately doubles as a result of receiving either a Score form or an Odds form. If we compare this to the coefficient on the interaction of income and school test scores, it implies that receiving a Score

framework, especially when not all families submit three choices. If parents choose schools to maximize utility, $U_{i j}=X_{i j} \beta+\varepsilon_{i j}$, then the likelihood function using all three choices is formed by calculating the probability that individual $i$ chooses schools $\left(j_{1}, j_{2}, j_{3}\right)$. This is the product of three probabilities: $P_{i}\left(j_{1}, j_{2}, j_{3}\right)=\operatorname{Pr}\left\{\left(U_{i j_{1}}>U_{i k} \forall k \in J_{i}^{1}\right) \cap\left(U_{i j_{2}}>U_{i k} \forall k \in J_{i}^{2}\right) \cap\left(U_{i j_{3}}>U_{i k} \forall k \in J_{i}^{3}\right)\right\}$.

${ }^{15}$ Hastings, Kane, and Staiger (2006a) find a peak in preferences for the percent of the school that is the student's own race, with white students preferring schools with a majority ( 70\%) of white students, and black students preferring schools with a majority $(\sim 70 \%)$ of black students, all else equal. In this population and in this fifth year of choice, we find that preferences for the percent black at a school are always decreasing for white students and always increasing for black students. Spline estimates in percent black indicated that for both cases, the linear function was a good fit. 
form has the same impact on revealed preference for test scores that a $\$ 64,700$ increase in household income would have. This implies that a family with income in the lowest quartile of the distribution would now behave like a family in the upper quartile of the income distribution when selecting schools based on average test score results. An important tradeoff that African American parents have to make is between school academic achievement and school racial composition. Without the Score form, an African American parent is willing to give up a 0.50 standard deviation in average test scores for a .34 increase in the fraction black at the school, all else equal. However, with the Score form, she would only be willing to give up a 0.21 standard deviation in average test scores for a .32 increase in the school fraction black.

The specification in Table VII allows the mean effect of receiving simplified information to vary with income. The effect of Score forms on preferences for school test scores does not seem to vary with income, as we found in the reduced form estimates in Table V. However, the effect of Odds forms is decreasing in income. Just as in the reduced-form results, it appears that information on admission odds encourages low-income families to choose higher-scoring schools more than it does for higher-income parents. For example, for a family with an income of $\$ 30,000$, receiving an Odds form increases the preference for test scores by 0.385 versus just receiving score information $(0.811+-10 *(-0.048)$ impact form Odds form versus 0.906 impact from Scores form). Alternatively, for a family with an income of $\$ 50,000$, receiving an Odds form decreases the preference for test scores by 0.575 versus just receiving score information $(0.811+10 *(-0.048)$ versus 0.906$)$. Note that both families place still higher weights on test scores when receiving an Odds form relative to receiving no simplified information at all.

Column 2 presents results using all three choices. The availability of more than one choice for students in CMS helps in the identification of the preference parameters, since it allows us to identify preferences for a particular school characteristic separately from a high draw on the additive logit error term $\left(\varepsilon_{i j}\right)$. The coefficients have the same signs as those in Column 1, but in some cases are statistically significantly different. In particular the mean preference for the home school is significantly lower, racial preferences decrease somewhat for both whites and African Americans, and the mean preference for test score decreases; however, coefficients on interactions with simplified information increase slightly, implying, if anything, a larger impact 
of simplified information on parental preferences. In particular, simplified information has a larger impact on preferences for test scores versus preferences for the guaranteed choice or school racial composition when we use all three choices instead of just the first choice.

We can use the results in Column 2 to perform a back of the envelope calculation - how much would the fraction of students choosing non-guaranteed schools change if all families in our sample had received simplified information on test scores? Even though the impact of receiving Score forms on the mean preference for test scores is large, the mean preference for the guaranteed choice is also large, indicating that it would take a substantial increase in the preference for test scores coupled with available high-scoring choices in close proximity in order to induce parents to choose a non-guaranteed school, even if their guaranteed choice is lowperforming. We can calculate the logit probability that each parent chooses a non-guaranteed choice for their child using the coefficients on test scores if the student received no form (0.556) or if the student received a Score form $(0.556+0.978)$. We can then calculate the difference in these two probabilities for each student and average them over students in our sample. When we do so, we find that the average increase in the probability of choosing a non-guaranteed school is 8 percentage points. This is similar in magnitude to the school-zone aggregated results in Column 2, Table IV, and to the student-level reduced-form estimates in Column 1, Table V. The 8 percentage point increase translates into a $26 \%$ increase in demand for non-guaranteed choices $(0.08 / 0.305)$. Hence, a small intervention would lead to a significant change in school choice participation.

\subsection{Effects on Siblings: Saliency and Lowered Information Costs}

Taken together, the school-zone aggregated regressions, the reduced-form student-level regressions, and the conditional logit results imply that simplified information has a significant impact on parental choice behavior. However it is not clear if the forms changed preferences through suggestion or salience (changing parents preferences), or through lowered information costs (enabling parents to act on their true preferences). In any experiment, these two mechanisms by which information can influence choice behavior are difficult to test apart. In order to examine which of these two mechanisms might be at work, we can examine the effect 
that receiving Score or Odds forms had on the choices parents made for other siblings at different levels in their schooling. Specifically, when a family receives a Score or Odds form from us for the elementary school child, they receive information only for elementary school choices and not for middle or high school choices. Hence we did not lower the family's cost of obtaining information for non-elementary school siblings. We can therefore test for an effect of simplified information on siblings in different education levels to see if the effect identified in the previous results is more consistent with the effect of saliency or lowered information costs on choice behavior. We focus on the non-NCLB group since our simplified information was grade-level specific, while the information that came with NCLB notification was not. The information that came with NCLB was the school-level proficiency rate for all schools in the district (from elementary through high school), so we do not have a difference in the within-family treatment for the NCLB population.

First, we identify siblings of students in the non-NCLB treatment and control groups. We count any student with the same last name living at the same address as a sibling. We then identify siblings who are not in the same school level as students in the non-NCLB treatment and control groups. By examining the impact on these students we may gain an understanding of whether the effect of simplified information on parental choice behavior is acting more through suggestion (receiving a form suggests to parents what they should focus on when choosing schools for their children) or through lowering the cost of gathering information on academic achievement and odds of admission. If the former is true, then we might expect to see a similar effect on siblings as those presented in Tables VII. If the latter is true, we might expect to see no effect on parents' choices for siblings of treated students.

Table VIII presents conditional logit results like those in Table VII, but using siblings of students in the non-NCLB treatment and control groups who are not in the same education level. In this sample a Score form indicates that a sibling in a different grade group received a Score form, and an Odds form indicates that the sibling received an Odds form. Overall we identified 1,788 siblings: 673 (37.6\%) from families that received Score forms and 334 (18.7\%) from families that received Odds forms. This is approximately the same percentage of students in the two treatment groups in the treatment and control sample. Table VIII shows no significant effect of 
simplified information on parental choices for siblings. While the mean coefficient on school test scores in both columns are very similar to those in Table VII, the coefficients on the interactions between information and school test scores are very different. The point estimates are near zero and if anything negative, indicating that receiving simplified information through Scores or Odds forms did not impact parents' preferences for siblings in different grades. This lends support to the hypothesis that simplified information affected parental choices through lowering information costs rather than through increased saliency or suggestion.

\section{Conclusion}

One of the most important topics in education policy is school choice and its effect on competition, student outcomes, and student sorting. School choice programs are gaining support as potential ways to introduce market forces into public education, by forcing schools to more efficiently produce higher quality education for all students. In fact, a key component of NCLB is the requirement that students at failing schools be given the option to choose to attend another non-failing schools. The goal is to allow lower-income students to benefit academically from attending higher-performing schools in other neighborhoods and to increase pressure on failing schools to improve through the (limited) introduction of market forces.

However, the extent to which market forces successfully lead to improved educational outcomes for all socio-economic groups depends on parents' choice behavior. As researchers have focused on the determinants of parental choice, there is mounting evidence that many parents, particularly in lower-income communities, do not choose schools for academic achievement. Although there is growing empirical evidence that low-income parents place lower weights on academics when choosing schools, there is little evidence as to why. Understanding the underlying cause of this preference disparity is critical for developing successful school choice programs.

Using a field experiment this paper finds evidence that providing simplified information on school-level academic achievement significantly increases revealed preferences for academic 
achievement. Receiving simplified information on test scores leads to an increase in choice participation and an increase in the average test scores of the schools chosen. We will be tracking these students to test if there are actual academic gains resulting from school choice for students who responded to simplified information by choosing higher-performing schools. This research project provides an opportunity to establish empirical links between information, choices, and academic performance.

Low-income parents may have truly lower expectations over the returns to education and academic achievement, or they may have higher information and decision-making costs. In fact, a requirement under the NCLB choice requirement is that parents be given clear and simple information on the academic performance at their school choice options. The Department of Education’s No Child Left Behind (NCLB) Public School Choice Guide states that "When all students ... are provided high-quality educational options, and when parents receive enough information to make intelligent choices among those options, public school choice can increase both equity and quality in education."16 By lowering information costs policy makers may enable families to act on their true preferences and fully benefit from school choice. Such a policy may have the added value of increasing competition and mitigating tendencies toward two-tiered systems under school choice. We find evidence that simplified information has significant impacts on parents' choices and implied preferences for school test scores, and that this impact seems to be primarily generated by lowering parents' information and decisionmaking costs.

\footnotetext{
${ }^{16}$ U.S. Department of Education. Public school choice. www.ed.gov/policy/elsec/guid/schoolchoiceguid.pdf. (Page 9).
} 


\section{REFERENCES}

Armor, David J., and Brett M. Peiser. (1998). Interdistrict choice in Massachusetts. In Paul E. Peterson and Bryan C. Hassel (Eds.), Learning from school choice. Washington, DC: Brookings Institution Press.

Bertrand, Marianne, Sendhil Mullainathan, and Eldar Shafir. (2006). Behavioral economics and marketing in aid of decision making among the poor. Journal of Public Policy and Marketing, 25(1), 8-23.

Caskey, John P. (1994). Fringe banking: Check-cashing outlets, pawnshops, and the poor. New York: Russell Sage Foundation.

Charlotte-Mecklenburg Schools. (2003). 2004-05 student assignment application guide. Charlotte: Author.

Choi, James J., David Laibson, and Brigitte C. Madrian. (2006). Reducing the complexity costs of 401(k) participation through Quick Enrollment ${ }^{\mathrm{TM}}$. NBER Working Paper No. 11979.

Duflo, Esther, William Gale, Jeffrey Liebman, Peter Orszag, and Emmanuel Saez. (2006). Saving incentives for low- and middle-income families: Evidence from a field experiment with H\&R Block. Quarterly Journal of Economics, 121(4), 1311-1346.

Fossey, Richard. (1994). Open enrollment in Massachusetts: Why families choose. Educational Evaluation and Policy Analysis, 16(3), 320-334.

Greene, Jay P., William G. Howell, and Paul E. Peterson. (1998). Lessons from the Cleveland Scholarship Program. In Paul E. Peterson and Brian C. Hassel (Eds.), Learning from school choice. Washington, DC: Brookings Institution Press.

Guryan, Jonathan, and Melissa S. Kearney. (2005). Lucky stores, gambling, and addiction: Empirical evidence from state lottery sales. NBER Working Paper No. 11287.

Hastings, Justine S., Thomas J. Kane, and Douglas O. Staiger. (2006a). Parental preferences and school competition: Evidence from a public school choice program. NBER Working Paper No. 11805. May 2006 version available at: www.econ.yale.edu/ jh529/Hastings_Kane_Staiger_QualityCompetition.pdf.

Hastings, Justine S., Thomas J. Kane, and Douglas O. Staiger. (2006b). Preferences and heterogeneous treatment effects in a public school choice lottery. NBER Working Paper No. 12145. June 2006 version available at: www.econ.yale.edu/ jh529/Hastings_Kane_Staiger_Preferences\&SchoolChoice.pdf. 
Hastings, Justine S., Thomas J. Kane, Douglas O. Staiger, and Jeffrey M. Weinstein. (forthcoming). The effect of randomized school admissions on voter participation. Journal of Public Economics.

Hastings, Justine S., and Jeffrey M. Weinstein. (2007). No Child Left Behind: Estimating the impact on choices and student outcomes. Manuscript, Yale University.

Jacob, Brian A., and Lars Lefgren. (forthcoming). What do Parents Value in Education? An Empirical Investigation of Parents' Revealed Preferences for Teachers. Quarterly Journal of Economics.

Kleitz, Bretten, George R. Weiher, Kent Tedin, and Richard Matland. (2000). Choice, charter schools, and household preferences. Social Science Quarterly, 81(3), 846-854.

Madrian, Brigitte C., and Dennis F. Shea. (2001). The power of suggestion: Inertia in 401(k) participation and savings behavior. Quarterly Journal of Economics, 116(4), 1149-1187.

McFadden, Daniel. (2006). Free markets and fettered consumers (Presidential Address to the American Economic Association). American Economic Review, 96(1), 5-29.

North Carolina State Board of Education. (2005). Consolidated state application accountability workbook. Available at www.ncpublicschools.org/docs/nclb/federal/consolidated/20050630workbook.pdf.

Schneider, Mark, and Jack Buckley. (2002). What do parents want from schools? Evidence from the Internet. Educational Evaluation and Policy Analysis, 24(2), 133-144.

Schneider, Mark, Melissa Marschall, Paul Teske, and Christine Roch. (1998). School choice and culture wars in the classroom: What different parents seek from education. Social Science Quarterly, 79(3), 489-501.

U.S. Department of Education. (2004). Public school choice. Available at www.ed.gov/policy/elsec/guid/schoolchoiceguid.pdf.

Vanourek, Greg, Bruno V. Manno, Chester E. Finn Jr., and Louann A. Bierlein. (1998). Charter schools as seen by students, teachers, and parents. In Paul E. Peterson and Brian C. Hassel (Eds.), Learning from school choice. Washington, DC: Brookings Institution Press.

Winter, Joachim, Rowilma Balza, Frank Caro, Florian Heiss, Byung-hill Jun, Rosa Matzkin, and Daniel McFadden. (2006). Medicare prescription drug coverage: Consumer information and preferences. Proceedings of the National Academy of Sciences, 103(20), 7929-7934. 
Table I: Summary Statistics

\begin{tabular}{|lccc|}
\hline Variable & $\begin{array}{c}\text { District } \\
(\mathbf{N}=\mathbf{1 2 5}, \mathbf{3 1 3})\end{array}$ & $\begin{array}{c}\text { Non-NCLB Students } \\
\text { in Sample } \\
\mathbf{( N = 6 , 3 2 8})\end{array}$ & $\begin{array}{c}\text { NCLB Students } \\
\text { in Sample } \\
(\mathbf{N}=\mathbf{1 0}, \mathbf{1 3 4})\end{array}$ \\
\hline Fraction Black & 0.457 & 0.600 & 0.688 \\
& $(0.498)$ & $(0.490)$ & $(0.463)$ \\
Fraction Lunch Recipients & 0.461 & 0.608 & 0.837 \\
& $(0.498)$ & $(0.488)$ & $(0.369)$ \\
Average Income & 56764 & 48767 & 35194 \\
& $(26915)$ & $(21278)$ & $(14943)$ \\
Average Test Score & & & \\
& & -0.341 & -0.532 \\
Average Number of Unexcused & 0.001 & $(0.829)$ & $(0.821)$ \\
Absences & $(0.944)$ & & \\
& 2.797 & 2.024 & 3.351 \\
$\begin{array}{l}\text { Fraction With at Least One Out- } \\
\text { of-School Suspension }\end{array}$ & $(5.518)$ & $(4.273)$ & $(5.437)$ \\
\hline
\end{tabular}

Note: Standard deviations are in parentheses.

${ }^{\dagger}$ Average test score is the average of reading and math scores on the North Carolina End-of-Grade exams. Only students in grades three through eight take these exams, so this variable is based on 47002 students in the district, 3376 students in the non-NCLB sample, and 4673 students in the NCLB sample.

Table II: Characteristics of Treatment and Control Groups and Choice Sets

\begin{tabular}{|lccc|}
\hline & $\begin{array}{c}\text { All Students } \\
(\mathbf{N}=\mathbf{1 6 , 4 6 2})\end{array}$ & $\begin{array}{c}\text { Non-NCLB } \\
\text { Students } \\
(\mathbf{N = \mathbf { 6 } , 3 2 8})\end{array}$ & $\begin{array}{c}\text { NCLB } \\
\text { Students } \\
\mathbf{( N = 1 0 , 1 3 4 )}\end{array}$ \\
\hline \hline Average Number of Schools in Choice Set & 14.440 & 14.728 & 14.261 \\
& $(4.904)$ & $(4.116)$ & $(5.330)$ \\
Average Range of Test Scores for Schools in & 1.294 & 1.325 & 1.275 \\
Choice Set & $(0.128)$ & $(0.132)$ & $(0.122)$ \\
Average Lowest Admission Odds for Schools & 0.277 & 0.252 & 0.293 \\
in Choice Set & $(0.127)$ & $(0.127)$ & $(0.124)$ \\
Average Home School Test Score & & & -0.524 \\
& -0.411 & -0.228 & $(0.167)$ \\
\hline
\end{tabular}

Note: Standard deviations are in parentheses. 
Table III: Average Baseline Characteristics

\begin{tabular}{|c|c|c|c|c|c|}
\hline & \multicolumn{3}{|c|}{$\begin{array}{c}\text { Sample Means and Standard } \\
\text { Deviations }\end{array}$} & \multicolumn{2}{|c|}{$\begin{array}{c}\text { Regression Adjusted } \\
\text { Mean Differences }\end{array}$} \\
\hline & $\begin{array}{l}\text { Score } \\
\text { Form }\end{array}$ & $\begin{array}{l}\text { Odds } \\
\text { Form }\end{array}$ & $\begin{array}{l}\text { Control } \\
\text { Group }\end{array}$ & $\begin{array}{l}\text { Score } \\
\text { Form }\end{array}$ & $\begin{array}{l}\text { Odds } \\
\text { Form }\end{array}$ \\
\hline Black & $\begin{array}{c}0.664 \\
(0.153)\end{array}$ & $\begin{array}{c}0.576 \\
(0.186)\end{array}$ & $\begin{array}{c}0.651 \\
(0.209)\end{array}$ & $\begin{array}{l}-0.008 \\
(0.042) \\
{[0.843]}\end{array}$ & $\begin{array}{c}-0.039 \\
(0.064) \\
{[0.545]}\end{array}$ \\
\hline Lunch Recipient & $\begin{array}{c}0.763 \\
(0.128)\end{array}$ & $\begin{array}{c}0.748 \\
(0.144)\end{array}$ & $\begin{array}{c}0.716 \\
(0.229)\end{array}$ & $\begin{array}{c}0.046 \\
(0.039) \\
{[0.242]}\end{array}$ & $\begin{array}{c}0.029 \\
(0.059) \\
{[0.627]}\end{array}$ \\
\hline Income & $\begin{array}{l}41725 \\
(8996)\end{array}$ & $\begin{array}{l}41573 \\
(8456)\end{array}$ & $\begin{array}{c}43334 \\
(13598)\end{array}$ & $\begin{array}{c}-1726 \\
(2301) \\
{[0.456]}\end{array}$ & $\begin{array}{c}-2392 \\
(3522) \\
{[0.499]}\end{array}$ \\
\hline Test Score $^{\dagger}$ & $\begin{array}{l}-0.402 \\
(0.224)\end{array}$ & $\begin{array}{l}-0.478 \\
(0.240)\end{array}$ & $\begin{array}{c}-0.460 \\
(0.311)\end{array}$ & $\begin{array}{c}0.064 \\
(0.059) \\
{[0.287]}\end{array}$ & $\begin{array}{l}-0.109 \\
(0.082) \\
{[0.187]}\end{array}$ \\
\hline $\begin{array}{l}\text { At Least One Out-of- } \\
\text { School Suspension }\end{array}$ & $\begin{array}{c}0.145 \\
(0.119)\end{array}$ & $\begin{array}{c}0.154 \\
(0.120)\end{array}$ & $\begin{array}{c}0.151 \\
(0.158)\end{array}$ & $\begin{array}{l}-0.027 \\
(0.021) \\
{[0.220]}\end{array}$ & $\begin{array}{l}-0.026 \\
(0.033) \\
{[0.429]}\end{array}$ \\
\hline $\begin{array}{l}\text { Number of Unexcused } \\
\text { Absences }\end{array}$ & $\begin{array}{c}2.829 \\
(1.763)\end{array}$ & $\begin{array}{c}2.889 \\
(1.292)\end{array}$ & $\begin{array}{l}2.550 \\
(2.037)\end{array}$ & $\begin{array}{l}-0.074 \\
(0.231) \\
{[0.749]}\end{array}$ & $\begin{array}{c}0.086 \\
(0.353) \\
{[0.809]}\end{array}$ \\
\hline Number of Observations & 33 & 11 & 33 & 77 & 77 \\
\hline
\end{tabular}

Notes: Adjusted differences report the coefficient on whether the school-zone received Score forms or Odds forms from separate OLS regressions with each variable in the first column as the dependent variable, controlling for randomization-block fixed effects. For adjusted differences, standard errors are in parentheses, and p-values are in brackets. Asterisks indicate significance $(*=.10, * *=.05, * * *=.01)$. ${ }^{\dagger}$ Average test score is the average of reading and math scores on the North Carolina End-of-Grade exams. Only students in grades three through eight take these exams, so this variable is based on 28 school-zones that received Score forms, 11 school-zones that received Odds forms, and 25 school-zones that were in the control group. 
Table IV: Regression-Adjusted Mean Differences in Aggregated Choice Behavior

\begin{tabular}{|c|c|c|c|c|c|c|}
\hline & \multicolumn{3}{|c|}{ Non-Weighted } & \multicolumn{3}{|c|}{ Weighted } \\
\hline & $\begin{array}{c}\text { (1) } \\
\text { All } \\
\text { Students }\end{array}$ & $\begin{array}{c}(2) \\
\text { Non- } \\
\text { NCLB } \\
\text { Students } \\
\end{array}$ & $\begin{array}{c}\text { (3) } \\
\text { NCLB } \\
\text { Students }\end{array}$ & $\begin{array}{c}\text { (4) } \\
\text { All } \\
\text { Students }\end{array}$ & $\begin{array}{c}\text { (5) } \\
\text { Non- } \\
\text { NCLB } \\
\text { Students } \\
\end{array}$ & $\begin{array}{c}\text { (6) } \\
\text { NCLB } \\
\text { Students }\end{array}$ \\
\hline \multicolumn{7}{|c|}{ Dep. Var.: Fraction Listing Non-Guaranteed Choice First } \\
\hline Score Form & $\begin{array}{c}0.025 \\
(0.028) \\
{[0.370]}\end{array}$ & $\begin{array}{c}0.066^{*} \\
(0.036) \\
{[0.074]}\end{array}$ & $\begin{array}{c}-0.028 \\
(0.044) \\
{[0.526]}\end{array}$ & $\begin{array}{c}0.007 \\
(0.026) \\
{[0.805]}\end{array}$ & $\begin{array}{c}0.073^{*} \\
(0.037) \\
{[0.053]}\end{array}$ & $\begin{array}{l}-0.028 \\
(0.038) \\
{[0.456]}\end{array}$ \\
\hline Odds Form & $\begin{array}{c}0.007 \\
(0.043) \\
{[0.863]}\end{array}$ & $\begin{array}{c}0.045 \\
(0.057) \\
{[0.434]}\end{array}$ & $\begin{array}{l}-0.047 \\
(0.065) \\
{[0.481]}\end{array}$ & $\begin{array}{c}-0.0004 \\
(0.039) \\
{[0.991]}\end{array}$ & $\begin{array}{c}0.079 \\
(0.060) \\
{[0.194]}\end{array}$ & $\begin{array}{l}-0.040 \\
(0.054) \\
{[0.463]}\end{array}$ \\
\hline Mean of Dep. Var. & 0.258 & 0.319 & 0.168 & 0.237 & 0.305 & 0.195 \\
\hline \multicolumn{7}{|c|}{ Dep. Var.: Average Number of Choices Listed } \\
\hline Score Form & $\begin{array}{c}0.107 \\
(0.077) \\
{[0.172]}\end{array}$ & $\begin{array}{l}0.239^{* *} \\
(0.104) \\
{[0.028]}\end{array}$ & $\begin{array}{c}-0.056 \\
(0.112) \\
{[0.621]}\end{array}$ & $\begin{array}{c}0.039 \\
(0.072) \\
{[0.587]}\end{array}$ & $\begin{array}{l}0.241^{* *} \\
(0.111) \\
{[0.037]}\end{array}$ & $\begin{array}{l}-0.062 \\
(0.096) \\
{[0.524]}\end{array}$ \\
\hline Odds Form & $\begin{array}{l}-0.010 \\
(0.118) \\
{[0.934]}\end{array}$ & $\begin{array}{c}0.018 \\
(0.165) \\
{[0.913]}\end{array}$ & $\begin{array}{l}-0.088 \\
(0.166) \\
{[0.601]}\end{array}$ & $\begin{array}{l}-0.034 \\
(0.106) \\
{[0.749]}\end{array}$ & $\begin{array}{c}0.141 \\
(0.181) \\
{[0.443]}\end{array}$ & $\begin{array}{l}-0.132 \\
(0.138) \\
{[0.348]}\end{array}$ \\
\hline Mean of Dep. Var. & 0.854 & 1.014 & 0.616 & 0.765 & 0.966 & 0.640 \\
\hline \multicolumn{7}{|c|}{ Dep. Var.: Average Difference in Test Score Between First Choice and Guaranteed Choice } \\
\hline Score Form & $\begin{array}{c}0.039 \\
(0.026) \\
{[0.136]}\end{array}$ & $\begin{array}{l}0.098^{* * *} \\
(0.029) \\
{[0.002]}\end{array}$ & $\begin{array}{l}-0.038 \\
(0.042) \\
{[0.375]}\end{array}$ & $\begin{array}{c}0.013 \\
(0.025) \\
{[0.603]}\end{array}$ & $\begin{array}{l}0.101^{* * *} \\
(0.027) \\
{[0.001]}\end{array}$ & $\begin{array}{c}-0.032 \\
(0.038) \\
{[0.417]}\end{array}$ \\
\hline Odds Form & $\begin{array}{c}0.055 \\
(0.040) \\
{[0.173]}\end{array}$ & $\begin{array}{l}0.108^{* *} \\
(0.046) \\
{[0.025]}\end{array}$ & $\begin{array}{c}-0.022 \\
(0.063) \\
{[0.724]}\end{array}$ & $\begin{array}{c}0.023 \\
(0.037) \\
{[0.535]}\end{array}$ & $\begin{array}{l}0.105^{* *} \\
(0.043) \\
{[0.021]}\end{array}$ & $\begin{array}{l}-0.021 \\
(0.055) \\
{[0.699]}\end{array}$ \\
\hline Mean of Dep. Var. & 0.136 & 0.142 & 0.128 & 0.142 & 0.136 & 0.146 \\
\hline Number of Observations & 77 & 46 & 31 & 77 & 46 & 31 \\
\hline
\end{tabular}

Notes: Separate OLS regressions for all students, non-NCLB students, and NCLB students controlling for randomization-block fixed effects (NCLB students are all in one randomization block). Standard errors are in parentheses, and p-values are in brackets. Weighted regressions weight by the number of students in each school-zone block. Asterisks indicate significance $(*=.10, * *=.05, * * *=.01)$. 
Table V: The Effect of Simplified Information on Student-Level Choices for Non-NCLB Students

\begin{tabular}{|c|c|c|c|}
\hline & $\begin{array}{c}\text { Dep. Variable: } \\
\text { Listed a Non- } \\
\text { Guaranteed Choice } \\
\text { First }\end{array}$ & $\begin{array}{c}\text { Dep. Variable: } \\
\text { Number of Choices } \\
\text { Listed }\end{array}$ & $\begin{array}{c}\text { Dep. Variable: } \\
\text { Difference in Test } \\
\text { Score Between } \\
\text { First Choice and } \\
\text { Guaranteed Choice } \\
\end{array}$ \\
\hline \multirow[t]{3}{*}{ Score Form } & $0.054^{*}$ & $0.172^{* *}$ & $0.081^{* * *}$ \\
\hline & $(0.028)$ & $(0.071)$ & $(0.025)$ \\
\hline & [0.053] & [0.017] & {$[0.001]$} \\
\hline \multirow[t]{3}{*}{ Score Form * Demeaned Income } & -0.001 & -0.002 & 0.00002 \\
\hline & $(0.001)$ & $(0.002)$ & $(0.001)$ \\
\hline & [0.321] & [0.409] & [0.983] \\
\hline \multirow[t]{3}{*}{ Odds Form } & $0.087^{* *}$ & $0.188^{*}$ & $0.137^{* * *}$ \\
\hline & $(0.035)$ & $(0.100)$ & $(0.043)$ \\
\hline & {$[0.016]$} & {$[0.062]$} & {$[0.002]$} \\
\hline \multirow[t]{3}{*}{ Odds Form * Demeaned Income } & $-0.003^{* *}$ & -0.003 & $-0.002^{* *}$ \\
\hline & $(0.001)$ & $(0.003)$ & $(0.001)$ \\
\hline & {$[0.026]$} & {$[0.308]$} & {$[0.044]$} \\
\hline \multirow[t]{3}{*}{ Black } & $0.099^{* * *}$ & $0.256^{* * *}$ & $0.030^{* * *}$ \\
\hline & $(0.018)$ & $(0.044)$ & $(0.014)$ \\
\hline & {$[0.000]$} & {$[0.000]$} & {$[0.030]$} \\
\hline \multirow[t]{3}{*}{ Lunch } & $-0.044^{*}$ & -0.044 & $-0.043^{* *}$ \\
\hline & $(0.023)$ & $(0.059)$ & $(0.018)$ \\
\hline & [0.061] & [0.458] & {$[0.016]$} \\
\hline \multirow[t]{3}{*}{ Ave. Distance to Schools W/n 5 Miles } & -0.004 & -0.010 & 0.011 \\
\hline & $(0.008)$ & $(0.023)$ & $(0.009)$ \\
\hline & [0.638] & {$[0.656]$} & [0.197] \\
\hline \multirow[t]{3}{*}{ Ave. Test Score of Schools W/n 5 Miles } & $0.082^{* * *}$ & 0.132 & $-0.079^{* *}$ \\
\hline & $(0.041)$ & $(0.123)$ & $(0.040)$ \\
\hline & {$[0.046]$} & {$[0.286]$} & {$[0.050]$} \\
\hline \multirow[t]{3}{*}{ Distance to Guaranteed School } & $0.016^{* * *}$ & $0.029^{*}$ & $-0.014^{*}$ \\
\hline & $(0.006)$ & $(0.016)$ & $(0.008)$ \\
\hline & [0.007] & [0.078] & [0.072] \\
\hline \multirow[t]{3}{*}{ Test Score at Guaranteed School } & $-0.259^{* * *}$ & $-0.512^{* * *}$ & -- \\
\hline & $(0.045)$ & $(0.136)$ & -- \\
\hline & {$[0.000]$} & {$[0.000]$} & -- \\
\hline \multirow[t]{3}{*}{ Demeaned Income } & $0.001^{* *}$ & 0.002 & -0.0004 \\
\hline & $(0.0005)$ & $(0.001)$ & $(0.0004)$ \\
\hline & [0.011] & [0.127] & {$[0.246]$} \\
\hline \multirow[t]{3}{*}{ In Magnet Program } & $0.143^{* * *}$ & $0.650^{* * * *}$ & $0.198^{* * *}$ \\
\hline & $(0.052)$ & $(0.115)$ & $(0.040)$ \\
\hline & {$[0.007]$} & {$[0.000]$} & {$[0.000]$} \\
\hline Mean of Dependent Variable & 0.305 & 0.966 & 0.136 \\
\hline Number of Observations & 6328 & 6328 & 6328 \\
\hline Adjusted R-Squared & 0.0626 & 0.0590 & 0.0800 \\
\hline
\end{tabular}

Notes: OLS estimation with randomization-block fixed effects. Standard errors (in parentheses) are clustered at the school-zone-grade level. P-values are in brackets. Asterisks indicate significance $(*=.10, * *=.05, * * *=.01)$. 
Table VI: The Effect of Simplified Information on Student-Level Choices for NCLB Students

\begin{tabular}{|c|c|c|c|}
\hline & $\begin{array}{c}\text { Dep. Variable: } \\
\text { Listed a Non- } \\
\text { Guaranteed Choice } \\
\text { First }\end{array}$ & $\begin{array}{c}\text { Dep. Variable: } \\
\text { Number of Choices } \\
\text { Listed }\end{array}$ & $\begin{array}{c}\text { Dep. Variable: } \\
\text { Difference in Test } \\
\text { Score Between } \\
\text { First Choice and } \\
\text { Guaranteed Choice }\end{array}$ \\
\hline \multirow[t]{3}{*}{ Score Form } & -0.017 & -0.007 & -0.030 \\
\hline & $(0.044)$ & $(0.105)$ & $(0.041)$ \\
\hline & {$[0.693]$} & {$[0.943]$} & {$[0.469]$} \\
\hline \multirow[t]{3}{*}{ Score Form * Demeaned Income } & -0.001 & -0.002 & -0.001 \\
\hline & $(0.001)$ & $(0.003)$ & $(0.001)$ \\
\hline & [0.181] & [0.529] & {$[0.275]$} \\
\hline \multirow[t]{3}{*}{ Odds Form } & -0.036 & -0.106 & -0.013 \\
\hline & $(0.049)$ & $(0.118)$ & $(0.055)$ \\
\hline & {$[0.472]$} & [0.368] & {$[0.810]$} \\
\hline \multirow[t]{3}{*}{ Odds Form * Demeaned Income } & 0.0002 & 0.002 & -0.0004 \\
\hline & $(0.001)$ & $(0.003)$ & $(0.001)$ \\
\hline & [0.905] & [0.594] & {$[0.736]$} \\
\hline \multirow[t]{3}{*}{ Black } & $0.046^{* * *}$ & $0.090^{* *}$ & $0.025^{* *}$ \\
\hline & $(0.013)$ & $(0.038)$ & $(0.012)$ \\
\hline & [0.001] & [0.018] & [0.037] \\
\hline \multirow[t]{3}{*}{ Lunch } & $-0.111^{* * * *}$ & $-0.248^{* * *}$ & $-0.091^{* * *}$ \\
\hline & $(0.019)$ & $(0.047)$ & $(0.019)$ \\
\hline & {$[0.000]$} & {$[0.000]$} & {$[0.000]$} \\
\hline \multirow[t]{3}{*}{ Ave. Distance to Schools W/n 5 Miles } & 0.001 & 0.001 & -0.002 \\
\hline & $(0.010)$ & $(0.028)$ & $(0.010)$ \\
\hline & [0.885] & {$[0.970]$} & [0.873] \\
\hline \multirow[t]{3}{*}{ Ave. Test Score of Schools W/n 5 Miles } & 0.044 & 0.168 & -0.019 \\
\hline & $(0.067)$ & $(0.183)$ & $(0.064)$ \\
\hline & {$[0.511]$} & [0.359] & {$[0.768]$} \\
\hline \multirow[t]{3}{*}{ Distance to Guaranteed School } & $0.013^{* * *}$ & $0.042^{* * *}$ & 0.006 \\
\hline & $(0.005)$ & $(0.012)$ & $(0.004)$ \\
\hline & {$[0.007]$} & {$[0.001]_{* * *}$} & {$[0.175]$} \\
\hline \multirow[t]{3}{*}{ Test Score at Guaranteed School } & $-0.200^{* * *}$ & $-0.631^{* * *}$ & -- \\
\hline & $(0.056)$ & $(0.168)$ & -- \\
\hline & {$[0.000]$} & {$[0.000]$} & -- \\
\hline \multirow[t]{3}{*}{ Demeaned Income } & 0.00005 & -0.0002 & -0.0001 \\
\hline & $(0.001)$ & $(0.002)$ & $(0.001)$ \\
\hline & {$[0.953]$} & {$[0.927]$} & {$[0.866]$} \\
\hline \multirow[t]{3}{*}{ In Magnet Program } & $0.082^{* * *}$ & $0.499^{* * *}$ & $0.191^{* * *}$ \\
\hline & $(0.023)$ & $(0.071)$ & $(0.066)$ \\
\hline & {$[0.000]$} & {$[0.000]$} & [0.004] \\
\hline Mean of Dependent Variable & 0.195 & 0.640 & 0.146 \\
\hline Number of Observations & 10134 & 10134 & 10134 \\
\hline Adjusted R-Squared & 0.0290 & 0.0341 & 0.0419 \\
\hline
\end{tabular}

Notes: OLS estimation with randomization-block fixed effects. Standard errors (in parentheses) are clustered at the school-zone-grade level. P-values are in brackets. Asterisks indicate significance $(*=.10, * *=.05, * * *=.01)$. 
Table VII: Effect of Simplified Information on Preferences, Non-NCLB Students

\begin{tabular}{|c|c|c|}
\hline & $\begin{array}{l}\text { Conditional Logit } \\
\text { (First Choice Only) }\end{array}$ & $\begin{array}{l}\text { Conditional Logit } \\
\text { (All Choices) }\end{array}$ \\
\hline Distance & $\begin{array}{l}-0.107^{* * *} \\
(0.016)\end{array}$ & $\begin{array}{l}-0.104^{* * *} \\
(0.014)\end{array}$ \\
\hline Home School & $\begin{array}{l}3.166^{* * *} \\
(0.131)\end{array}$ & $\begin{array}{l}2.461^{* * *} \\
(0.115)\end{array}$ \\
\hline School Test Score & $\begin{array}{l}0.735^{* * *} \\
(0.177)\end{array}$ & $\begin{array}{l}0.556^{* * *} \\
(0.131)\end{array}$ \\
\hline School Test Score * Demeaned Income & $\begin{array}{l}0.014^{* * *} \\
(0.004)\end{array}$ & $\begin{array}{l}0.012^{* * *} \\
(0.004)\end{array}$ \\
\hline School Test Score * Score Form & $\begin{array}{l}0.906^{* * *} \\
(0.208)\end{array}$ & $\begin{array}{l}0.978^{* * *} \\
(0.206)\end{array}$ \\
\hline $\begin{array}{l}\text { School Test Score * Demeaned Income * } \\
\text { Score Form }\end{array}$ & $\begin{array}{c}0.002 \\
(0.007)\end{array}$ & $\begin{array}{c}0.005 \\
(0.007)\end{array}$ \\
\hline School Test Score * Odds Form & $\begin{array}{l}0.811^{* * *} \\
(0.157)\end{array}$ & $\begin{array}{l}0.839^{* * *} \\
(0.140)\end{array}$ \\
\hline $\begin{array}{l}\text { School Test Score * Demeaned Income * } \\
\text { Odds Form }\end{array}$ & $\begin{array}{l}-0.048^{* * *} \\
(0.009)\end{array}$ & $\begin{array}{l}-0.039^{* * *} \\
(0.008)\end{array}$ \\
\hline Fraction Black at School & $\begin{array}{l}-1.153^{* * *} \\
(0.360)\end{array}$ & $\begin{array}{l}-0.947^{* * *} \\
(0.263)\end{array}$ \\
\hline Fraction Black at School * Black Student & $\begin{array}{l}2.228^{* * *} \\
(0.351)\end{array}$ & $\begin{array}{l}1.867^{* * *} \\
(0.304)\end{array}$ \\
\hline Log Pseudolikelihood & -8463.3336 & -16101.46 \\
\hline Number of Observations & 93198 & 93198 \\
\hline
\end{tabular}


Table VIII: Effect of Simplified Information on Preferences, Non-NCLB Siblings

\begin{tabular}{|c|c|c|}
\hline & $\begin{array}{l}\text { Conditional Logit } \\
\text { (First Choice Only) }\end{array}$ & $\begin{array}{l}\text { Conditional Logit } \\
\text { (All Choices) }\end{array}$ \\
\hline Distance & $\begin{array}{c}-0.156^{* * *} \\
(0.020)\end{array}$ & $\begin{array}{c}-0.167^{* * *} \\
(0.020)\end{array}$ \\
\hline Current School & $\begin{array}{l}5.650^{* * *} \\
(0.231)\end{array}$ & $\begin{array}{l}5.182^{* * *} \\
(0.223)\end{array}$ \\
\hline Home School & $\begin{array}{l}1.887^{* * *} \\
(0.180)\end{array}$ & $\begin{array}{l}1.502^{* * *} \\
(0.162)\end{array}$ \\
\hline School Test Score & $\begin{array}{c}0.560 \\
(0.342)\end{array}$ & $\begin{array}{l}0.717^{* *} \\
(0.285)\end{array}$ \\
\hline School Test Score * Demeaned Income & $\begin{array}{c}0.007 \\
(0.012)\end{array}$ & $\begin{array}{c}0.004 \\
(0.009)\end{array}$ \\
\hline School Test Score $*$ Score Form & $\begin{array}{c}0.056 \\
(0.443)\end{array}$ & $\begin{array}{c}0.131 \\
(0.401)\end{array}$ \\
\hline $\begin{array}{l}\text { School Test Score * Demeaned Income * } \\
\text { Score Form }\end{array}$ & $\begin{array}{c}0.012 \\
(0.013)\end{array}$ & $\begin{array}{c}0.007 \\
(0.012)\end{array}$ \\
\hline School Test Score * Odds Form & $\begin{array}{l}-0.048 \\
(0.506)\end{array}$ & $\begin{array}{l}-0.175 \\
(0.495)\end{array}$ \\
\hline $\begin{array}{l}\text { School Test Score * Demeaned Income * } \\
\text { Odds Form }\end{array}$ & $\begin{array}{c}0.008 \\
(0.017)\end{array}$ & $\begin{array}{l}-0.008 \\
(0.019)\end{array}$ \\
\hline Fraction Black at School & $\begin{array}{c}-1.329^{* * *} \\
(0.448)\end{array}$ & $\begin{array}{c}-1.274^{* * *} \\
(0.398)\end{array}$ \\
\hline Fraction Black at School * Black Student & $\begin{array}{l}1.742^{* * *} \\
(0.596)\end{array}$ & $\begin{array}{l}2.150^{* * *} \\
(0.551)\end{array}$ \\
\hline $\begin{array}{l}\text { Log Pseudolikelihood } \\
\text { Number of Observations }\end{array}$ & $\begin{array}{c}-586.7509 \\
29265\end{array}$ & $\begin{array}{c}-887.6255 \\
29265\end{array}$ \\
\hline
\end{tabular}

Notes: Standard errors are clustered at the family level. Asterisks indicate significance $(*=.10, * *=.05, * * *=.01)$. 
Figure 1: Example of a Score Form

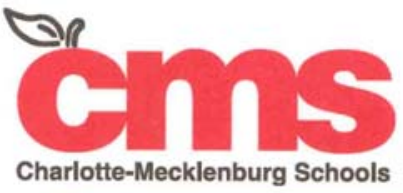

\section{Fast Facts About Your Choice Options}

This table shows student test performance levels at each 20062007 school choice option for your transportation zone.

\begin{tabular}{|c|l|}
\hline Test Score* & School Name and Program \\
\hline $\mathbf{8 8} \%$ & Villa Heights LI/TD \\
\hline $\mathbf{8 5} \%$ & Tuckaseegee LI/TD \\
\hline $\mathbf{8 1} \%$ & Elizabeth Traditional (East Grey Zone) \\
\hline $\mathbf{8 0} \%$ & Smith Language Academy \\
\hline $\mathbf{8 0} \%$ & Myers Park Traditional (West Grey Zone) \\
\hline $\mathbf{7 5} \%$ & Oakhurst Open/Paideia \\
\hline $\mathbf{7 3} \%$ & Morehead Math/Sci/Env Studies \\
\hline $\mathbf{7 3} \%$ & First Ward Accelerated Learning \\
\hline $\mathbf{7 1} \%$ & Highland Mill Montessori \\
\hline $\mathbf{7 0} \%$ & University Park Arts \\
\hline $\mathbf{6 9} \%$ & Irwin Ave. Open/Paideia \\
\hline $\mathbf{6 8} \%$ & Hornets Nest Communication Arts \\
\hline $\mathbf{6 7} \%$ & Winding Springs Leadership \\
\hline $\mathbf{6 5} \%$ & Barringer Elementary \\
\hline $\mathbf{6 5} \%$ & Lincoln Heights Elementary \\
\hline $\mathbf{6 5} \%$ & Westerly Hills Elementary \\
\hline $\mathbf{6 3} \%$ & Bruns Elementary \\
\hline $\mathbf{6 3} \%$ & Druid Hills Elementary \\
\hline $\mathbf{6 3} \%$ & Walter G. Byers Elementary \\
\hline $\mathbf{6 3} \%$ & Nathaniel Alexander Elementary \\
\hline $\mathbf{6 2} \%$ & Ashley Park Elementary \\
\hline $\mathbf{6 1} \%$ & Reid Park Elementary \\
\hline $\mathbf{6 0} \%$ & Thomasboro Elementary \\
\hline $\mathbf{N e w ~ S c h o o l ~}$ & Irwin Ave. IB \\
\hline $\mathbf{N e w ~ S c h o o l ~}$ & Oaklawn Language (K-4) \\
\hline $\mathbf{4}$ & \\
\hline
\end{tabular}

Your Home School is: Druid Hills Elem. Your Home School Test Score is: $63 \%$

If you would like your child to attend a school other thanyour home school, you must submit a choice form.

You may submit up to 3 choices, and you are always guaranteed a spot at your home school.

*This score is the average reading and math test score performance on the End of Grade exam for students at this school in the 2004-2005

school year. Information on school-level test score performance can be

found for all schools at the CMS web site: www.cms.k12.nc.us.

Prepare for greatness. 
Figure 2: Example of an Odds Form

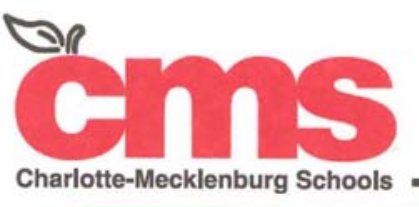

\section{Fast Facts About Your Choice Options}

This table shows student test performance levels at each 20062007 school choice option for your transportation zone.

\begin{tabular}{|l|l|l|}
\hline Test Score* & Admit Chance** & School Name and Program \\
\hline $88 \%$ & $62 \%$ & Villa Heights LI/TD \\
\hline $85 \%$ & $95 \%$ & Tuckaseegee LI/TD \\
\hline $81 \%$ & $65 \%$ & Elizabeth Traditional (East Grey Zone) \\
\hline $80 \%$ & $75 \%$ & Smith Language Academy \\
\hline $80 \%$ & $75 \%$ & Myers Park Traditional (West Grey Zone) \\
\hline $75 \%$ & $98 \%$ & Oakhurst Open/Paideia \\
\hline $73 \%$ & $95 \%$ & Morehead Math/Sci/Env Studies \\
\hline $73 \%$ & $45 \%$ & First Ward Accelerated Learning \\
\hline $71 \%$ & $49 \%$ & Highland Mill Montessori \\
\hline $70 \%$ & $92 \%$ & University Park Arts \\
\hline $69 \%$ & $88 \%$ & Irwin Ave. Open/Paideia \\
\hline $68 \%$ & $83 \%$ & Hornets Nest Communication Arts \\
\hline $67 \%$ & $96 \%$ & Winding Springs Leadership \\
\hline $65 \%$ & $68 \%$ & Barringer Elementary \\
\hline $65 \%$ & $98 \%$ & Lincoln Heights Elementary \\
\hline $65 \%$ & $98 \%$ & Westerly Hills Elementary \\
\hline $63 \%$ & $100 \%$ & Bruns Elementary \\
\hline $63 \%$ & $100 \%$ & Druid Hills Elementary \\
\hline $63 \%$ & $100 \%$ & Walter G. Byers Elementary \\
\hline $63 \%$ & $100 \%$ & Nathaniel Alexander Elementary \\
\hline $62 \%$ & $100 \%$ & Ashley Park Elementary \\
\hline $61 \%$ & $100 \%$ & Reid Park Elementary \\
\hline $60 \%$ & $100 \%$ & Thomasboro Elementary \\
\hline New School & New School & Irwin Ave. IB \\
\hline New School & New School & Oaklawn Language (K-4) \\
\hline & & \\
\hline$Y$ & $96 \%$ & 6 \\
\hline
\end{tabular}

Your Home School is: Hidden Valley Elem.

Your Home School Test Score is: $\mathbf{6 3} \%$

If you would like your child to attend a school other than your home school, you must submit a choice form.

You may submit up to 3 choices, and you are always guaranteed a spot at your home school.

-This score is the average reading and math test score performance on the End of Grade exam for strdents at this schoolin the 2004 2005 school year. Information on school-level test score performance can be found for all schools at the CMS web site: www.cnis.k12. nc.us. ${ }^{* *}$ The Admit Chance is the percent of students who listed this choice as their first choice and were admitted through the lottery or off of the wait list for the 2005-2006 school year.

Prepare for greatness. 